\title{
UTJECAJ UČINAKA PRIVREMENIH RAZLIKA NA OBJEKTIVNOST FINANCIJSKOG IZVJEŠTAVANJA U REPUBLICI HRVATSKOJ SUKLADNO NOVIM POREZNIM PROPISIMA
}

\begin{abstract}
Osnovni cilj financijskih izvještaja kao konačnog proizvoda financijskog računovodstva je pružiti fer i objektivan prikaz financijskog položaja i financijske uspješnosti poslovnog subjekta. To pretpostavlja primjenu računovodstvenih načela u potpunosti, odnosno obuhvaćanje financijskih učinaka poslovnih transakcija u svojoj cjelosti $i$ u skladu s prirodom poslovnog događaja, a nikako djelomično. Djelomično obuhvaćanje poslovnih događaja ima za posljedicu neobjektivno i nepravedno financijsko izvještavanje, bilo kroz precjenjivanje bilo kroz podcjenjivanje elementa odnosno određenih pozicija elemenata financijskih izvještaja. To također znači da neevidentiranje poreznih učinaka privremenih razlika znači nepotpunu primjenu računovodstvenih načela MRS-a 12 - Porez na dobit, odnosno HSFI 14 - Vremenska razgraničenja, što može značiti da financijski izvještaji nisu fer i objektivni. Stvarna, odnosno ekonomska posljedica nastanka i postojanja privremenih razlika, čiji porezni učinci nisu obuhvaćeni po načelima iz MRS-a 12 ili HSFI 14, je podcjenjivanje ili pak precjenjivanje dobiti nakon
\end{abstract}

* Dr. sc. P. Anić-Antić, Anić-Antić \& Sesar porezno savjetovanje d. o. o. (E-mail: pasko.anicantic@as-poreznosavjetovanje.hr).

** Mr. sc. I. Idžojtić, Javorović, Idžojtić \& partneri j. t. d. (E-mail: ivan.idzojtic@poreznosavjetovanje.com.hr).

*** D. Sesar, MBA, Anić-Antić \& Sesar porezno savjetovanje d. o. o. (E-mail: davor.sesar@ as-poreznosavjetovanje.hr).

Rad je primljen u uredništvo 13.12.2017. godine, a prihvaćen je za objavu 27.03.2018. 
P ANIĆ-ANTIĆ, I. IDŽOJTIĆ, D. SESAR: Utjecaj učinka privremenih razlika na objektivnost financijskog izvještavanja... EKONOMSKI PREGLED, 69 (6) 744-763 (2018)

oporezivanja, što znači podcijenjeni ili precijenjeni kapital odnosno podcijenjenu ili precijenjenu neto imovinu (sa svim u konačnici financijskim učincima na obujam i strukturu raspoređivanja dobiti). Zapravo, konačna posljedica je u tome što financijski izvještaji nisu objektivni ni istiniti.

Ključne riječi: privremene razlike, MRS 12, HSFI 14, financijski izvještaji, međunarodni računovodstveni standardi, porez na dobit, porezna osnovica

\section{Uvod}

Prema Okviru za sastavljanje i prezentiranje financijskih izvještaja, bilo međunarodnih bilo hrvatskih, osnovni cilj financijskih izvještaja kao konačnog proizvoda financijskog računovodstva je pružiti prvenstveno vanjskim korisnicima informacije o financijskom položaju, financijskoj uspješnosti te novčanim tokovima u svrhu donošenja ekonomskih odluka. Također, prema čl. 19. Zakona o računovodstvu (NN 78/15; 134/15; 120/16) kao temeljnom aktu zakonodavnog okvira financijskog izvještavanja, financijski izvještaji moraju pružiti istinit i pravedan prikaz financijskog položaja i uspješnosti poslovanja poduzetnika. Istinito i pravedno financijsko izvještavanje pretpostavlja primjenu računovodstvenih načela u potpunosti, odnosno obuhvaćanje financijskih učinaka poslovnih transakcija u svojoj cjelosti i u skladu s prirodom poslovnog događaja, a nikako djelomično. Djelomično obuhvaćanje poslovnih događaja ima za posljedicu neobjektivno i nepravedno financijsko izvještavanje, bilo kroz precjenjivanje bilo kroz podcjenjivanje elementa odnosno određenih pozicija elemenata financijskih izvještaja. Samo na taj način financijski izvještaji mogu ostvariti svoj osnovni cilj pružanja informacija o financijskom položaju, financijskoj uspješnosti i novčanim tokovima određenog poslovnog subjekta. Iz navedenog proizlazi da neevidentiranje poreznih učinaka privremenih razlika znači nepotpunu primjenu računovodstvenih načela MRS-a 12 - Porez na dobit, odnosno HSFI 14 - Vremenska razgraničenja, što može značiti da financijski izvještaji nisu pravedni ni objektivni. Naime, evidentiranjem poreznih učinaka privremenih razlika izjednačava se efektivna stopa oporezivanja s nominalnom, što u konačnici znači da kad je riječ o privremenim razlikama, neto dobit razdoblja za raspodjelu je dobit utvrđena prema računovodstvenim načelima umanjena za porezni rashod utvrđen prema važećoj nominalnoj stopi oporezivanja (u Republici Hrvatskoj $18 \%$ ili $12 \%$ ), odnosno kao da tih privremenih razlika nije niti bilo. To u konačnici znači da će u godini nastanka privremenih razlika, neto dobit razdoblja (za raspodjelu) biti veća (za iznos poreznog učinka privremenih razlika) jer sukladno računovodstvenim načelima iz MRS-a 
12 isti ne bi trebali imati utjecaj na raspodjelu (porez treba platiti u vremenu kad dođe do povećanja imovine ili smanjenja obveza, a ne zbog privremenog priznavanja odnosno nepriznavanja određenih rashoda ili prihoda, odnosno na taj način se pokušava eliminirati utjecaj različitosti poreznih propisa na dobit razdoblja za potrebe raspodjele).

\section{Predmet i cilj istraživanja}

Kao što je u Uvodu navedeno, financijski izvještaji trebaju svojim korisnicima za potrebe odlučivanja pružiti informacije koje fer i objektivno prikazuju financijski položaj, financijsku uspješnost i novčane tokove poslovnog subjekta. Utvrđeni porezni rashod iskazan u bilanci i računu dobiti i gubitka trgovačkog društva utječe direktno na njegov financijski položaj i uspješnost poslovanja. S obzirom da se porezni rashod razdoblja sastoji od tekućeg poreza utvrđenog kroz prijavu poreza na dobit i odgođenog poreza u visini poreznog učinka privremenih razlika, vidljivo je da privremene razlike odnosno njihov porezni učinak mogu imati direktan utjecaj na iskazivanje poreznog razdoblja trgovačkog društva. Računovodstvena načela propisuju potrebu i način evidentiranja poreznog učinka privremenih razlika, dok porezni propisi utvrđuju oblik i vrijeme nastanka i nestanka (ukidanja) privremenih razlika. Stoga su porezni propisi osnovni predmet istraživanja ovoga rada, odnosno utvrđivanje privremenih razlika kroz privremeno nepriznavanje određenih rashoda i prihoda razdoblja. $U$ te svrhe detaljno će se istražiti novi porezi propisi iz važećeg Zakona o porezu na dobit (NN 177/04, 90/05, 57/06, 146/08, 80/10, 22/12, 148/13, 143/14, 50/16 i 115/16.) i važećeg Pravilnika o porezu na dobit (NN 95/05, 133/07, 156/08, 146/09, 123/10, 137/11, 61/12, 146/12, 160/13, 12/14, 157/14, 137/15, 1/17.). Posebno će se istražiti i objasniti promjene poreznih propisa kod primjene tzv. novčanog načela utvrđivanja porezne osnovice, gdje u punoj mjeri dolazi do izražaja potreba za punom primjenom računovodstvenih načela vezanih za utvrđivanje i evidentiranje poreznih učinaka privremenih razlika, kako bi zbog direktnog utjecaja utvrđivanja poreznog rashoda na financijski položaj i uspješnost poslovanja, u svojoj konačnici financijski izvještaji bili pravedni i objektivni. Dosadašnji porezni propisi načelno su dopuštali nastanak privremenih razlika samo na strani rashoda (tzv. Metoda odgode), a samim time i užu osnovu za pogrešnim financijskim izvještavanjem. Novi porezni propisi dopuštaju nastanak privremenih razlika i na strani prihoda (tzv. Metoda obveze), što se može smatrati novitetom i najznačajnijom promjenom u odnosu na sve dosadašnje porezne propise koji su bili na snazi u RH. To s druge strane također ima za posljedicu i širu osnovu odnosno mogućnost za nepravedno i neobjektivno financijsko izvještavanje, što će biti posebno istraženo i obrazloženo u ovome radu. 
Cilj je istraživanja ovoga rada, a u skladu s navedenim predmetom istraživanja, ukazati primjenjenim metodama deskripcije (za opisivanje računovodstvenih načela, metoda i postupaka vezanih za evidentiranje poreznih učinaka privremenih razlika i važećih poreznih propisa u skladu, nakon provedene porezne reforme od strane Ministarstva financija Republike Hrvatske) i metodom komparacije (za usporedbu financijskih učinaka neevidentiranja poreznih učinaka nastanka odnosno nestanka privremenih razlika) na nužnost potpune primjene računovodstvenih načela vezanih za porez na dobit sadržanim u MRS 12 i HSFI 14 kako bi financijski izvještaji bili pošteni i objektivni.

Također je cilj istraživanja ovoga rada utvrditi činjenicu da primjena novčanog načela utvrđivanja poreznog rashoda poslovnog subjekta čini znatno širu osnovu za moguću pojavu neobjektivnog financijskog izvještavanja uslijed šire primjene poreznih propisa vezanih uz pojave privremenih razlika (i na strani prihoda za razliku od dosadašnjeg kada su se u RH načelno javljali samo na strani rashoda), a time i veće pojave neevidentiranjem poreznog učinka privremenih razlika sukladno odredbama MRS 12 odnosno HSFI 14.

\section{Ocjena dosadašnjih istraživanja}

Stručna i znanstvena literatura koja je do sada istraživala ili opisivala privremene razlike općenito, a posebno evidentiranje poreznih učinaka nastalih/nestalih privremenih razlika u Republici Hrvatskoj nije široko i posebno obrađivana. Širi obuhvat pristupu definiranja vrsta i oblika privremenih razlika te evidentiranju poreznih učinaka istih obradili su P. Anić-Antić i I. Idžojtić u svom radu „Privremene razlike i učinci privremenih razlika na objektivnost financijskog izvještavanja u RH“, objavljenog u Ekonomskom pregled br. 11., Zagreb 2012. U navedenom radu autori detaljno opisuju pravno i ekonomsko određenje privremenih razlika odnosno razlikovanje računovodstvene i porezne dobiti te povezanost financijskih izvještaja i porezne prijave. Također se $u$ članku detaljno navode vrste privremenih razlika i njihov financijski učinak iskazan u financijskim izvještajima. $U$ te svrhe detaljno su opisani financijski učinci kako stalnih tako i privremenih razlika te način evidentiranja poreznog učinka istih u poslovnim knjigama poslovnog subjekta. Vrste i učinci privremenih razlika opisanih i obrađenih u radu posljedica su tada važećih poreznih propisa odnosno tada važećih odredbi Zakona i Pravilnika o porezu na dobit.

Problematika privremenih razlika detaljno je, na praktičnim primjerima, obrađena i u udžbeniku „Računovodstvo poreza“, grupe autora: Šimović, Hrvoje; Dragija, Martina; Dražić Lutilsky, Ivana; Primorac, Marko; Zagreb 2015; ISBN: 
978-953-3460-17-8., u dijelu koji govori o oporezivanju dobiti odnosno povezanosti financijskih izvještaja i prijave poreza na dobit. Udžbenik je nastao kao rezultat suradnje između autora s Katedre za računovodstvo i Katedre za financije Ekonomskog fakulteta - Zagreb, a namijenjen je studentima iz kolegija „Računovodstvo poreza" koji se izvodi kao izborni predmet na diplomskome studiju smjera Računovodstvo i revizija.

Problematiku privremenih razlika obradio je i Š. Guzić u radu „Knjiženje poreza na dobitak - odgođeni porez“, objavljenom u stručnom časopisu Računovodstvo Revizija i Financije broj 3 iz 2015. godine. U svom članku autor prikazuje poslovne događaje koji u određenim okolnostima mogu dovesti do pojave odgođene porezne imovine i odgođene porezne obveze.

Stoga se u ovome radu autori neće posebno baviti dijelom koji se odnosi na vrste privremenih razlika i način njihovog evidentiranja s obzirom da se računovodstvena načela u tom dijelu načelno nisu značajno mijenjala, već će posebna pozornost i time nadogradnja na gore navedene i objavljene radove biti usmjerena na problematiku privremenih razlika u skladu s novim poreznim propisima. Posebno će se istražiti i obraditi mogućnost pojave privremenih razlika kod poduzetnika koji za potrebe utvrđivanja poreznog rashoda primjenjuju tzv. novčano načelo. Primjena novčanog načela je najveća i najznačajnija promjena u odnosu na sve dosadašnje porezne propise koji su određivali područje privremenih razlika odnosno opseg primjene računovodstvenih načela koji uređuju računovodstveno evidentiranje učinaka privremenih razlika uključujući bilo metodu odgode bilo metodu obveze.

\section{Privremene razlike}

Privremene razlike definirane su u Međunarodnom računovodstvenom standardu 12 - Porez na dobit (za one koji po Zakonu o računovodstvu primjenjuju MRS/MSFI), odnosno u Hrvatskom standardu financijskog izvještavanja 14 Vremenska razgraničenja (za one koji po Zakonu o računovodstvu primjenjuju HSFI), kao razlike između računovodstvene dobiti i oporezive dobiti koje nastaju u jednom poreznom razdoblju (godini), a ukidaju se, odnosno poništavaju, u budućim poreznim razdobljima.

Moguća su dva slučaja privremenih razlika. Prema računovodstvenim standardima privremene razlike mogu biti oporezive privremene razlike i odbitne privremene razlike.

Oporezive privremene razlike privremene su razlike koje će imati za posljedicu oporezive iznose pri određivanju oporezive dobiti (poreznog gubitka) u bu- 
dućim razdobljima kada će knjigovodstveni iznos sredstava biti vraćen ili obveza podmirena. Zapravo, ove privremene razlike nastaju ako je računovodstvena dobit veća od oporezive dobiti, a u budućnosti će kod ukidanja biti suprotno, tj. računovodstvena će dobit biti manja od oporezive dobiti. Porezni učinak ove privremene razlike iskazuje se primjenom metode obveze.

Odbitne privremene razlike privremene su razlike koje će imati za posljedicu iznose koji se mogu odbiti pri određivanju oporezive dobiti (poreznog gubitka) budućeg razdoblja u kojemu će knjigovodstveni iznos sredstava biti vraćen ili obveza podmirena - porez na dobit plaćen „danas“. Zapravo, ove privremene razlike nastaju ako je računovodstvena dobit manja od oporezive dobiti, a u budućnosti će kod ukidanja biti suprotno, tj. računovodstvena dobit će biti veća od oporezive dobiti. Porezni učinak ove privremene razlike iskazuje se primjenom metode odgode (Anić-Antić; Idžojtić, 2012.).

Porezni učinci privremenih razlika iskazuju se u financijskim izvještajima, na bilančnim pozicijama odgođene porezne imovine i na pozicijama pasive kao odgođena porezna obveza, te u izvještaju o dobiti kao stavka ukupnog poreznog rashoda pri utvrđivanju neto rezultata razdoblja (ukupni porezni rashod obuhvaća tekući porez i odgođeni porez).

\subsection{Privremene razlike u Republici Hrvatskoj}

Prema poreznim propisima koji su bili na snazi do 31. prosinca 2016. godine, proizlazilo je da privremene razlike u Hrvatskoj mogu nastati kao posljedica privremenih razlika kod rashoda. Međutim, odredbama čl. 5., st. 7. Zakona (Zakon o izmjenama i dopunama zakona o porezu na dobit, NN 115/16), kod poreznih obveznika koji za potrebe utvrđivanja osnovice poreza na dobit primjenjuju tzv. novčano načelo, moguć je širi obuhvat privremenih razlika, odnosno, iste mogu nastati kao posljedica privremenih razlika i kod prihoda. To znači da se pored odbitnih privremenih razlika javljaju i oporezive privremene razlike. Navedene promjene čine veliku i značajnu novost u utvrđivanju porezne osnovice, a samim time i u financijskom izvještavanju u Republici Hrvatskoj.

\subsection{Prikrivene oporezive privremene razlike u Republici Hrvatskoj}

Privremene razlike mogu nastati ako je računovodstvena dobit veća od oporezive dobiti, a u budućnosti će po istoj osnovi biti suprotno i time se ukinuti (pri- 
mjenjuje se po MRS-u 12 ,metoda obveze”). U Republici Hrvatskoj ovaj slučaj nije postojao, a novim Zakonom o izmjenama i dopunama zakona o porezu na dobit, za porezno razdoblje koje počinje od 1. siječnja 2017. godine, za porezne obveznike primjene tzv. novčanog načela, daje se zakonita mogućnost odgađanja (premještanja) plaćanja poreza na dobit. Za sve ostale porezne obveznike takva mogućnost i dalje nije moguća, a formalno je spriječena definicijom polazne veličine kao dobiti po računovodstvenim propisima što znači da su računovodstveni prihodi i rashodi načelno istovjetni poreznima. Naime, kod tih poreznih obveznika pojava privremenih razlika je moguća, ali je prikrivena (Anić-Antić; Idžojtić, 2012.). Znači, učinak ovakve privremene razlike u dijelu odgađanja plaćanja poreza je moguć, ali je prikriven, odnosno, omogućeno je porezno kreditiranje kroz priznavanje rashoda od amortizacije čiji pozitivni financijski učinak nije vidljiv u financijskim izvještajima. Dakle, specifičnost je u postojanju prikrivene oporezive privremene razlike. Sadržan je u rashodima priznatim u svrhe oporezivanja i to po osnovi amortizacije, vrijednosnih usklađenja i rezerviranja. Primarno i dominanto učinak ovakve privremene razlike u dijelu odgađanja plaćanja poreza sadržan je u amortizaciji priznatoj u svrhe poreza na dobit. To je do te mjere naglašeno da je obilježje našega propisa o oporezivanju dobiti porezno kreditiranje kroz priznavanje rashoda od amortizacije.

a) Prikrivena privremena razlika - kod rashoda amortizacije

Amortizacija je sustavni raspored amortizacijskog iznosa imovine tijekom njezina korisnog vijeka upotrebe, odnosno razdoblja u kojem se očekuje da će poduzetnik upotrebljavati imovinu, tj. da će mu ista biti dostupna za upotrebu ili broj proizvoda ili sličnih jedinica koje poduzetnik očekuje ostvariti od te imovine. To znači da rashod amortizacije utvrđen primjenom odgovarajuće metode treba odraŽavati okvir očekivanog trošenja budućih ekonomskih koristi imovine od strane subjekta. Međutim, amortizacija za potrebe oporezivanja određena je Zakonom o porezu na dobit, kao najviše dopustivi porezno priznati rashod te se kao takav priznaje i u svrhu financijskog izvještavanja. To znači da se računovodstvena načela za utvrđivanje računovodstvene dobiti uglavnom ne podudaraju s poreznim načelima u svrhu utvrđivanja porezne osnovice $\mathrm{u}$ istom obračunskom razdoblju te se javljaju privremene razlike. U tome slučaju porezni obveznik pri utvrđivanju iznosa poreza na dobit koji je iskazan u Računu dobiti i gubitka treba postupati u skladu s načelima izraženima u Međunarodnom računovodstvenom standardu 12 Porez na dobit, odnosno Hrvatskom standardu financijskog izvještavanja 14 Vremenska razgraničenja, a u cilju fer i objektivnog financijskog izvještavanja. 
P ANIĆ-ANTIĆ, I. IDŽOJTIĆ, D. SESAR: Utjecaj učinka privremenih razlika na objektivnost financijskog izvještavanja... EKONOMSKI PREGLED, 69 (6) 744-763 (2018)

\section{Primjer:}

Obveznik poreza na dobit stavio je u upotrebu nekretninu (građevinu) u prosincu 2007. godine. Prema Zakonu o porezu na dobit propisana stopa amortizacije je $5 \%$ godišnje, a može se i povećati, ali najviše do udvostručenja tj. do $10 \%$ godišnje. Porezni obveznik je koristio baš tu, u poreznom smislu, najvišu dopuštenu stopu amortizacije od $10 \%$ godišnje. Primjenjujući ekonomska načela, pouzdano se procjenjuje da će ta imovina biti upotrebljavana 40 godina odnosno da je ekonomska stopa amortizacije $2,5 \%$ godišnje.

\section{Tablica 1 .}

\section{IZRAČUN PRIKRIVENIH PRIVREMENIH RAZLIKA I NIHOV FINANCIJSKI UČINAK}

$\mathrm{u} \mathrm{kn}$

\begin{tabular}{|c|c|c|c|c|c|c|c|c|c|c|}
\hline \multirow{2}{*}{ Godina } & \multirow{2}{*}{$\begin{array}{c}\text { Osnovica } \\
\text { za amor- } \\
\text { tizaciju }\end{array}$} & \multicolumn{2}{|c|}{$\begin{array}{c}\text { Amortizacija } \\
\text { po ekonomskim } \\
\text { načelima }\end{array}$} & \multicolumn{2}{|c|}{$\begin{array}{l}\text { Amortizacija } \\
\text { po poreznim } \\
\text { načelima }\end{array}$} & \multicolumn{3}{|c|}{$\begin{array}{c}\text { Knjigovodstvena vrijednost } \\
\text { nekretnine }\end{array}$} & \multirow{2}{*}{$\begin{array}{c}\text { Privre- } \\
\text { mena } \\
\text { razlika }\end{array}$} & \multirow{2}{*}{$\begin{array}{l}\text { Porezni } \\
\text { učinak } \\
\text { privr- } \\
\text { mene } \\
\text { razlike }\end{array}$} \\
\hline & & $\begin{array}{l}\text { Stopa } \\
\text { u \% }\end{array}$ & Iznos & Stopa & Iznos & $\begin{array}{c}\text { Po } \\
\text { ekonomskim } \\
\text { načelima }\end{array}$ & $\begin{array}{c}\text { Po } \\
\text { poreznim } \\
\text { načelima }\end{array}$ & Razlika & & \\
\hline 1 & 2 & 3 & $4(2 * 3)$ & 5 & $6(2 * 5)$ & 7 & 8 & $9(7-8)$ & $10(6-4)$ & 11 \\
\hline 2008. & 500.000 & 2,50 & 12.500 & 10,00 & 50.000 & 487.500 & 450.000 & 37.500 & 37.500 & 7.500 \\
\hline 2009. & 500.000 & 2,50 & 12.500 & 10,00 & 50.000 & 475.000 & 400.000 & 75.000 & 37.500 & 7.500 \\
\hline 2010. & 500.000 & 2,50 & 12.500 & 10,00 & 50.000 & 462.500 & 350.000 & 112.500 & 37.500 & 7.500 \\
\hline 2011. & 500.000 & 2,50 & 12.500 & 10,00 & 50.000 & 450.000 & 300.000 & 150.000 & 37.500 & 7.500 \\
\hline 2012. & 500.000 & 2,50 & 12.500 & 10,00 & 50.000 & 437.500 & 250.000 & 187.500 & 37.500 & 7.500 \\
\hline 2013. & 500.000 & 2,50 & 12.500 & 10,00 & 50.000 & 425.000 & 200.000 & 225.000 & 37.500 & 7.500 \\
\hline 2014. & 500.000 & 2,50 & 12.500 & 10,00 & 50.000 & 412.500 & 150.000 & 262.500 & 37.500 & 7.500 \\
\hline 2015. & 500.000 & 2,50 & 12.500 & 10,00 & 50.000 & 400.000 & 100.000 & 300.000 & 37.500 & 7.500 \\
\hline 2016. & 500.000 & 2,50 & 12.500 & 10,00 & 50.000 & 387.500 & & 337.500 & 37.500 & 7.500 \\
\hline 2017. & 500.000 & 2,50 & 12.500 & 10,00 & 50.000 & 375.000 & 0 & \begin{tabular}{|l}
375.000 \\
\end{tabular} & 37.500 & 6.750 \\
\hline I. & & & \multicolumn{5}{|c|}{$\begin{array}{l}\text { UKUPNO VIŠE (UNAPRIJED) OBRAČUNATA } \\
\text { AMORTIZACIJA }\end{array}$} & \multicolumn{3}{|c|}{375.000} \\
\hline II. & & & \multicolumn{5}{|c|}{ STOPA POREZA NA DOBIT } & \multicolumn{3}{|c|}{$20 \%$ i $18 \%$} \\
\hline III. & & & \multicolumn{5}{|c|}{$\begin{array}{l}\text { POREZNI UČINAK PRIVREMENE RAZLIKE (I. x } \\
\text { II.) - ODGOĐENI POREZ }\end{array}$} & \multicolumn{3}{|c|}{74.250} \\
\hline 2018. & 500.000 & 2,50 & 12.500 & & 0 & 362.500 & 0 & 362.500 & -12.500 & -2.250 \\
\hline 2019. & 500.000 & 2,50 & 12.500 & & 0 & 350.000 & 0 & 350.000 & -12.500 & -2.250 \\
\hline 2020. & 500.000 & 2,50 & 12.500 & & 0 & 337.500 & 0 & 337.500 & -12.500 & -2.250 \\
\hline 2021. & 500.000 & 2,50 & 12.500 & & 0 & 325.000 & 0 & 325.000 & -12.500 & -2.250 \\
\hline 2022. & 500.000 & 2,50 & 12.500 & & 0 & 312.500 & 0 & 312.500 & -12.500 & -2.250 \\
\hline $\begin{array}{l}\text { od } 2023 . \\
\text { do } 2040 .\end{array}$ & 500.000 & 2,50 & 312.500 & & 0 & 0 & 0 & 0 & -312.500 & -56.250 \\
\hline Ukupno & & & 500.000 & & 500.000 & & & & & \\
\hline
\end{tabular}

Izvor: Autori 
Obračunavajući amortizaciju do maksimalno porezno priznatog iznosa (stupac 6), a ne prema ekonomskim načelima o amortizaciji, porezni obveznik je kumulativno do 31. prosinca 2017. god. više, odnosno prekomjerno obračunao amortizaciju u iznosu od 375.000 kuna. Zbog toga je u poslovnim knjigama na dan 31. prosinca 2017. godine za taj isti iznos podcijenjena neotpisana vrijednost dugotrajne imovine (stupac 9) odnosno izamortizirana je i iskazana u iznosu od 0 kuna (stupac 8) umjesto u iznosu od 375.000 kuna (stupac 7). Ta prekomjerno obračunata amortizacija zapravo je unaprijed obračunata amortizacija. Ona nije prihvatljiva po ekonomskim načelima vrednovanja imovina, ali je prihvatljiva po poreznim propisima što znači da je porezno priznati rashod, za razdoblje amortizacije u razdoblju od 2008. do 2017. godine. Nakon 2017. godine amortizacije u porezne svrhe više nema. Ona bi postojala da se amortizacija obračunavala po ekonomskim načelima, ali bi tada u prvih deset godina porezna amortizacija bila jednaka manjoj ekonomskoj i ne bi postojala unaprijed obračunata amortizacija. U iznosu unaprijed obračunate amortizacije sadržan je povoljni porezni (financijski) učinak za poreznog obveznika. On se utvrđuje uz primjenu stope poreza na dobit od $12 \%$ ili $18 \%$ (u primjeru je $18 \%$ ), tako da zaključno s 2017. godinom iznosi 375.000 x $20 \%$ i $18 \%$ za 2017. godinu $=74.250$ kuna. To je zapravo iznos odgođenog poreza ili, financijski se to izjednačava s beskamatnim poreznim kreditom. Nakon desete godine, a u preostalom razdoblju ekonomskog vijeka upotrebe imovine, odgođeni porez će dospjeti i porezni kredit će se morati vratiti. Cijeli iznos će se vratiti u preostalih trideset i jednu godinu, a godišnje u visini 1/30 ukupnog iznosa odgođenog poreza (ukupnog poreznog kredita). Kada bi poreznim propisom bilo predviđeno plaćanje kamata na ovako nastale porezne kredite, porezni obveznici bi donosili odluke o njegovom korištenju odnosno o visini obračunane amortizacije prema rezultatima financijskog promišljanja o prihvatljivosti korištenja poreznog kredita (financijska poluga), dakle kao i kod odlučivanja o svakom drugom financijskom zaduživanju. Ali porezni propisi ne sadrže obvezu plaćanja kamata na ovakve porezne kredita, pa ih porezni obveznici koriste čim više mogu. Besplatni su. Štoviše, smanjenjem porezne stope poreznim propisima koji su u primjeni od 2017. godine s $20 \%$ na $18 \%$ ili $12 \%$, porezni obveznik je u još povoljnijem položaju jer je imao uštedu u iznosu porezne stope od $20 \%$, a vraćat će u idućim razdobljima ekonomskog vijeka trajanja imovine po stopi od $18 \%$ ili 12 $\%$ (za njega bi rizik postojao da se promjenom poreznih propisa stopa poreza na dobit povećala), što je u konačnici trajni gubitak državnog proračuna.

Za poreznog obveznika svi opisani financijski učinci temeljem porezno priznate amortizacije, su povoljni, ali i privremeni i u obliku odgođenog plaćanja poreza na dobit - beskamatnog poreznog kredita. Oni su u financijskom smislu istovjetni učincima vremenskih (privremenih) razlika kod kojih je u godini nastanka računovodstvena dobit veća od oporezive dobiti, a u godini ukidanja obrnuto (primjenjuje se po MRS-u 12 ,metoda obveze”). Međutim, specifičnost naših po- 
reznih propisa je da omogućavaju navedene učinke isključivo uz uvjet istodobnog iskazivanja i u računovodstvu. Zbog toga nije omogućena razlika između računovodstvene i oporezive dobiti koja bi bila vremenska razlika s primjenom metode obveze pa taj privremeno povoljni financijski učinak neće biti iskazan u pasivi bilance na stavci „Odgođeno plaćanje poreza na dobit”. Budući da je u financijskom smislu ostvaren, ali nije iskazan u bilanci, privremeno povoljni financijski učinak poreza na dobit je prikriven. To ima dvije posljedice. Prva je da financijski izvještaji nisu pošteni što stvara potrebu za njihovim ispravljanjem. Druga posljedica je u tome što se ukupni iznos prikrivene privremene razlike amortizacije zadržava u financiranju poslovanja kao raspoloživi novčani tok, dakle ne samo u visini odgođenog plaćanja poreza na dobit nego i u visini ostatka vremenske razlike koji predstavlja odgođenu neto dobit. U slučaju da ova privremena razlika nije prikrivena, neto dobit ne bi bila odgođena i bila bi raspoloživa za raspodjelu. Financijske učinke prikrivenih privremenih razlika i njihov utjecaj na financijski položaj društva prikazujemo u sljedećoj tablici.

\section{Tablica 2.}

\section{UTJECAJ FINANCIJSKOG UČINKA PRIKRIVENIH PRIVREMNIH RAZLIKA NA FINANCIJSKI POLOŽAJ}

$\mathrm{u} \mathrm{kn}$

\begin{tabular}{|c|c|c|c|c|c|c|}
\hline \multirow{2}{*}{$\begin{array}{l}\text { Dan izvje- } \\
\text { štavanja }\end{array}$} & \multirow{2}{*}{$\begin{array}{l}\text { Trošak } \\
\text { stjecanja }\end{array}$} & \multicolumn{2}{|c|}{$\begin{array}{c}\text { Knjigovodstvena } \\
\text { vrijednost }\end{array}$} & \multirow{2}{*}{$\begin{array}{l}\text { Podcije- } \\
\text { njena vri- } \\
\text { jednost } \\
\text { imovine }\end{array}$} & \multirow{2}{*}{$\begin{array}{l}\text { Podcije- } \\
\text { njena } \\
\text { vrijednost } \\
\text { obveza }\end{array}$} & \multirow{2}{*}{$\begin{array}{l}\text { Podcije- } \\
\text { njena vri- } \\
\text { jednost } \\
\text { kapitala }\end{array}$} \\
\hline & & \begin{tabular}{|c|} 
po \\
ekonomskim \\
načelima
\end{tabular} & \begin{tabular}{l}
\multicolumn{1}{c}{ po } \\
poreznim \\
načelima
\end{tabular} & & & \\
\hline 1 & 2 & 3 & 4 & 5 & 6 & 7 \\
\hline 31.12.2008. & 500.000 & 487.500 & 450.000 & 37.500 & 6.750 & 30.750 \\
\hline 31.12.2009. & 500.000 & 475.000 & 400.000 & 75.000 & 13.500 & 61.500 \\
\hline 31.12.2010. & 500.000 & 462.500 & 350.000 & 112.500 & 20.250 & 92.250 \\
\hline 31.12.2011. & 500.000 & 450.000 & 300.000 & 150.000 & 27.000 & 123.000 \\
\hline 31.12.2012. & 500.000 & 437.500 & 250.000 & 187.500 & 33.750 & 153.750 \\
\hline 31.12.2013. & 500.000 & 425.000 & 200.000 & 225.000 & 40.500 & 184.500 \\
\hline 31.12.2014. & 500.000 & 412.500 & 150.000 & 262.500 & 47.250 & 215.250 \\
\hline 31.12.2015. & 500.000 & 400.000 & 100.000 & 300.000 & 54.000 & 246.000 \\
\hline 31.12.2016. & 500.000 & 387.500 & 50.000 & 337.500 & 60.750 & 276.750 \\
\hline 31.12.2017. & 500.000 & 375.000 & 0 & 375.000 & 67.500 & 307.500 \\
\hline
\end{tabular}

Izvor: autori 
$\mathrm{Na}$ dan 31. prosinca 2017. godine društvo u svojoj bilanci ima podcijenjenu imovinu u iznosu od $375.000 \mathrm{kn}$, a kao posljedica primjene poreznih načela koja u biti postaju i računovodstvena. U svojoj biti radi se o unaprijed obračunatoj amortizaciji. Isto tako, podcijenjena je i vrijednost obveza u ukupnom iznosu od 67.500 kuna, što u svojoj biti čini porezni kredit na ime odgođenog plaćanja obveze poreza na dobit. Na kraju, podcjenjena je i vrijednost kapitala u ukupnom iznosu od 307.500 kuna što u svojoj biti čini odgođenu neto dobit za raspodjelu. Posljedično, financijski izvještaji nisu fer ni objektivni.

b) Prikrivena privremena razlika - kod rashoda od vrijednosnog usklađenja potraživanja od kupaca

Potraživanja su, na temelju obveznopravnih i drugih osnova, zasnovana prava potraživati od dužnika plaćanje duga, isporuku usluga ili pružanje usluga. Na svaki datum bilance poduzetnik procjenjuje postoji li objektivan dokaz o umanjenju vrijednosti pojedinog potraživanja. Ako postoji objektivan dokaz, poduzetnik će pristupiti vrijednosnom usklađenju istih. Tako utvrđen računovodstveno utvrđeni rashod od vrijednosnog usklađenja u svrhu utvrđivanja osnovice poreza na dobit priznaje se sukladno poreznim propisima. Prema čl. 9. Zakona o porezu na dobit, vrijednosna usklađenja po osnovi ispravka vrijednosti potraživanja od kupaca za isporučena dobra i obavljene usluge, priznaju se kao rashod ako je od dospijeća potraživanja do kraja poreznog razdoblja proteklo više od šezdeset (60) dana, a ista nisu naplaćena do petnaestog dana prije dana podnošenja porezne prijave. Svote vrijednosnih usklađenja potraživanja od kupaca iskazane u prethodnim poreznim razdobljima kao porezno priznati rashod uključuju se u prihode, ako do trenutka nastupa zastae prava na naplatu nisu poduzete sve radnje za osiguranje naplate duga u skladu s odredbama čl. 2. Zakona o porezu na dobit (tzv. pažnja dobrog gospodarstvenika).

\section{Primjer:}

- Društvo ima nenaplaćeno potraživanje od kupca za prodanu robu u iznosu od $100.000 \mathrm{kn}$.

- Potraživanja su starija od 60 dana od dana bilanciranja (31. prosinca 2017.).

- Menadžment je donio odluku da se ista vrijednosno usklade u istom iznosu (zbog porezno priznatog rashoda).

- Menadžment je procjenio da će se navedena potraživanja naplatiti te istom kupcu i dalje isporučuje robu.

- Krajem naredne poslovne godine društvo je naplatilo cjelokupno potraživanje koje je bilo vrijednosno usklađeno. 
Na dan izvještavanja 31. prosinca 2017. godine javlja se razlika između poreznih i računovodstvenih (ekonomskih) načela u priznavanju rashoda. Prema čl. 9. Zakona i članu 33. Pravilnika o porezu na dobit potraživanja od kupaca porezno priznati rashod ukoliko je od dana dospjeća potraživanja do kraja poslovne godine prošlo više od 60 dana. Menadžment poduzeća procijenio je da će navedena potraživanja biti naplaćena $i$ stoga im i dalje isporučuje robu (očekivana ekonomska korist od pritjecanja novčanih sredstava). Dakle, ovdje je samo iskorištena zakonska mogućnaost smanjenja tekuće porezne obveze (po poreznim načelima). Stoga se temeljem takve odluke menadžmenta ovdje javljaju nevidljive privremene razlike kao odgođena porezna obveza, te je u svrhu fer i objektivnog financijskog izvještavanja, u poslovnim knjigama poduzetnika potrebno evidentirati nastale nevidljive privremene razlike. Nakon knjiženja nevidljive privremene razlike na imovinskom kontu „Prekomjerno umanjenje - do razine porezno priznatih rashoda” imovina društva je vraćena na razinu njene ekonomske vrijednosti. Rezultat toga je i u pasivi nastajenje odgođene obveze poreza na dobit (u visini tekuće porezne stope - $18 \%$ ) i odgođene neto dobiti (do pokrića imovinom). Bilo bi poželjno iznos ovako utvrđene privremne razlike, za iznos prekomjernog umanjenja imovine do iznosa ispravke vrijednosti, evidentirati unutar grupe 12 kontnog plana jer se u istoj grupi evidentiraju i potraživanja od kupaca. Razlog za takvo evidentiranje nalazimo u tome da se za potrebe izvještavanja učinak privremene razlike zaista i događa na poziciji imovine uz koju je i nastala ta privremena razlika (potraživanje od kupaca će u našoj bilanci biti iskazano zaista u visini ekonomske vrijednosti tog potraživanja).

U godini naplate usklađenih potraživanja za Društvo će se stvoriti uvjeti $\underline{u k i-}$ danja privremenih razlika. Shodno tome, pokrićem imovinom, odgođena porezna obveza postaje tekuća, kao i odgođena neto dobit.

\subsection{Oporezive privremene razlike kod primjene tzv. Novčanog načela utvrđivanja osnovice poreza na dobit}

Sukladno čl. 5., st. 7. i 8., porezni obveznik koji u prethodnom poreznom razdoblju nije ostvario prihode veće od 3.000.000,00 kuna može poreznu osnovicu utvrditi prema novčanom načelu. Prema novčanom načelu financijski učinci poslovnih događaja priznaju se tek u trenutku u kojemu su novac i novčani ekvivalenti primljeni ili isplaćeni. U skladu s tim, prema ovome načelu ne priznaju se nenovčane transakcije, nerealizirani prihodi $i$ dobitci te nerealizirani rashodi i gubitci. Po naplati/plaćanju ili po realizaciji stavki koji su dodatno umanjili ili uvećali poreznu osnovicu iz ovoga članka iste se uključuju u poreznu osnovicu. Sukladno tome, porezna osnovica dodatno se: 
a) uvećava za:

1. rashode (gubitke) od vrijednosnih usklađenja dugotrajne materijalne i nematerijalne imovine

2. rashode (gubitke) od vrijednosnih usklađenja financijske imovine

3. rashode vrijednosnog usklađenja potraživanja od kupca za isporučena dobra i obavljene usluge

4. rashode od rezerviranja

5. rashode od nerealiziranih tečajnih razlika

6. rashode od ostalih nenovčanih transakcija

7. smanjenja potraživanja od poslovnih aktivnosti

8. smanjenja kratkotrajnih potraživanja po osnovi kamata priznatih u prihode

9. smanjenja zaliha

10. povećanja kratkoročnih obveza od poslovnih aktivnosti

11. povećanja kratkoročnih obveza po osnovi kamata priznatih u rashode

12. ostale korekcije koje povećavaju dobit

b) umanjuje za:

1. prihode od vrijednosnih usklađenja financijske imovine

2. prihode od rezerviranja

3. prihode od nerealiziranih tečajnih razlika

4. prihode od ostalih nenovčanih transakcija

5. povećanja potraživanja od poslovnih aktivnosti

6. povećanja kratkotrajnih potraživanja po osnovi kamata priznatih u prihode

7. povećanja zaliha

8. smanjenja kratkoročnih obveza od poslovnih aktivnosti

9. smanjenja kratkoročnih obveza po osnovi kamata priznatih u rashode

10. ostale korekcije koje smanjuju dobit.

Iz navedenih odredbi proizlazi da u Republici Hrvatskoj, kod poreznih obveznika koji primjenjuju novčano načelo pri utvrđivanju osnovice poreza na dobit, privremene razlike mogu nastati kao posljedica privremenih razlika na strani rashoda i na strani prihoda. Znači, novim poreznim propisima kod 
poreznih obveznika koji primjenjuju novčano načelo pri utvrđivanju osnovice poreza na dobit moguće je ne priznati i određene prihode iskazane u računovodstvu. Nepriznavanje prihoda kod utvrđivanja osnovice poreza na dobit znači da je računovodstvena dobit poreznog razdoblja veća od oporezive dobiti, a u budućnosti ce kod ukidanja biti suprotno tj. računovodstvena dobit će biti manja od oporezive dobiti, odnosno, javljaju se oporezive privremene razlike. Oporezive privremene razlike su privremene razlike koje će imati za posljedicu oporezive iznose pri određivanju oporezive dobiti (poreznog gubitka) u budućim razdobljima kada će knjigovodstveni iznos sredstava biti vraćen ili obveza podmirena. Porezni učinak ove privremene razlike iskazuje se primjenom metode obveze.

\section{Primjer:}

- Porezni obveznik je u poreznom razdoblju ostvario prihode u iznosu od 1.000.000,00 kuna i rashode u iznosu od 800.000,00 kuna.

- U poreznom razdoblju porezni obveznik nije naplatio potraživanja na ime kojih je u poslovnim knjigama priznao prihode u iznosu od 200.000,00 kuna.

- U poreznom razdoblju porezni obveznik nije platio svoje obveze u iznosu od 100.000 kn na ime kojih je u svojim poslovnim knjigama priznao poslovne rashode.

U prijavi poreza na dobit (Obrazac PD-NN), porezni obveznik ce iskazati sljedeće:

DOBIT/ GUBITAK IZ RAČUNA DOBITI I GUBITKA:

- Prihodi $=1.000 .000,00 \mathrm{kn}$

- Rashodi $=800.000,00 \mathrm{kn}$

- Dobit $=200.000,00 \mathrm{kn}$

- Porezno priznati prihodi (prema novčanom načelu) $=1.000 .000,00-$ $200.000=\underline{800.000} \underline{\mathrm{kn}}$

- Porezno priznati rashodi (prema novčanom načelu) $=800.000-100.000=$ $\underline{700.000 \mathrm{kn}}$

- Porezna osnovica prema novčanom načelu $=\underline{100.000,00 \mathrm{kn}}$

POREZNA OBVEZA PREMA NOVČANOM NAČELU $(12 \%)=12.000,00 \mathrm{kn}$

U ovom slučaju javljaju se privremene razlike i na strani prihoda i na strani rashoda. Sukladno odredbama MRS 12- Porez na dobit, u poslovnim knjigama u 
godina nastanka privremenih razdoblja treba evidentirati porezni učinak nastalih privremenih razlika. Stoga, a što je vidljivo iz gore navedenog primjera, u poslovnim knjigama poreznog obveznika treba iskazati:

a) odgođenu poreznu imovinu metodom odgode (odbitne privremene razlike) na osnovicu $100.000 \mathrm{kn}$ (povećana porezna osnovica zbog porezno nepriznatih rashoda uslijed neplaćenih obveza tekućeg razdoblja na ime kojih je u poslovnim knjigama poreznog obveznika priznat poslovni rashod), odnosno porezni učinak privremene razlike u iznosu od 12.000,00 kn (100.000 x $12 \%$ ), a u korist dobiti prije oporezivanja (klasa 8)

b) odgođenu poreznu obvezu metodom obveze (oporezive privremene razlike) na osnovicu $200.000 \mathrm{kn}$ (smanjena porezna osnovica zbog porezno nepriznatih rashoda uslijed nenaplaćenih potraživanja tekućeg razdoblja na ime kojih je u poslovnim knjigama poreznog obveznika priznat poslovno prihod), odnosno porezni učinak privremene razlike u iznosu od 24.000,00 kn (200.000 x $12 \%)$, a na teret dobiti prije oporezivanja (klasa 8).

Utjecaj evidentiranja odnosno neevidentiranja poreznog učinka privremenih razlika u godini nastanka privremenih razlika bio bi kako slijedi:

a) evidentiranje poreznog učinka privremenih razlika:

- dobit prije oporezivanja $=200.000 \mathrm{kn}$

- porez na dobit $\quad=12.000 \mathrm{kn}$

- odgođena porezna imovina $=12.000 \mathrm{kn}$

- odgođena porezna obveza $=24.000 \mathrm{kn}$

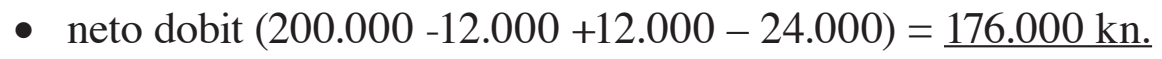

b) neevidentiranje poreznog učinka privremenih razlika:

- dobit prije oporezivanja $=200.000 \mathrm{kn}$

- porez na dobit $\quad=12.000 \mathrm{kn}$

- odgođena porezna imovina $=0 \mathrm{kn}$

- odgođena porezna obveza $=0 \mathrm{kn}$

- neto dobit $(200.000-12.000)=\underline{188.000 \mathrm{kn}}$.

Iz navedenog primjera vidljivo je da nepostupanje s računovodstvenim načelima priznavanja poreznih učinaka privremenih razlika u godini njihova nastanka, odnosno neevidentiranjem poreznih učinaka nastalih privremenih razlika, dolazi do nerealno iskazane dobiti tekućeg razdoblja, odnosno nerealno iskazanog kapitala. Posljedično, financijski izvještaji poreznog obveznika nisu pošteni ni objektivni. 
P ANIĆ-ANTIĆ, I. IDŽOJTIĆ, D. SESAR: Utjecaj učinka privremenih razlika na objektivnost financijskog izvještavanja... EKONOMSKI PREGLED, 69 (6) 744-763 (2018)

Kada se potraživanja od 200.000,00 kuna naplate i plate obveze u inosu od $100.000,00$ kuna ista se uključuju u poreznu osnovicu u tom razdoblju. To znači, da će, u godini nestanka, djelomično ili u potpunosti, privremenih razlika (naplate nenaplaćenih potraživanja i plaćanja neplaćenih obveza), u poslovnim knjigama poreznog obveznika imati za posljedicu smanjenje odnosno ukidanje prethodno iskazane odgođene porezne imovine i/ili odgođene porezne obveze. Uz pretpostavku da je porezni obveznik u idućem poreznom razdoblju naplatio sva nenaplaćena potraživanja (200.000 kn) i platio sve neplaćene obveze (100.000 kn) koje se odnose na prethodno porezno razdoblje, učinak istog prikazujemo kako slijedi:

DOBIT/ GUBITAK IZ RAČUNA DOBITI I GUBITKA:

- Prihodi 1.000.000,00 kn

- Rashodi 800.000,00 kn

- Dobit 200.000,00 kn

- Porezno priznati prihodi (prema novčanom načelu) $=1.000 .000,00+$ $200.000=1.200 .000 \mathrm{kn}$

- Porezno priznati rashodi (prema novčanom načelu) $=800.000+100.000=$ $900.000 \mathrm{kn}$

- Porezna osnovica prema novčanom načelu $=300.000,00$ kn

POREZNA OBVEZA PREMA NOVČANOM NAČELU $(12 \%)=36.000,00 \mathrm{kn}$

Utjecaj evidentiranja poreznog učinka privremenih razlika u godini nestanka (ukidanja) privremenih razlika:

a) evidentiranje poreznog učinka privremenih razlika:

- dobit prije oporezivanja $=200.000 \mathrm{kn}$

- porez na dobit $=36.000 \mathrm{kn}$

- odgođena porezna imovina $=-12.000 \mathrm{kn}$

- odgođena porezna obveza $=+24.000 \mathrm{kn}$

- neto dobit $(200.000-36.000-12.000+24.000)=\underline{176.000 \mathrm{kn}}$.

b) neevidentiranje poreznog učinka privremenih razlika:

- dobit prije oporezivanja $=200.000 \mathrm{kn}$

- porez na dobit $\quad=36.000 \mathrm{kn}$

- odgođena porezna imovina $=0 \mathrm{kn}$

- odgođena porezna obveza $=0 \mathrm{kn}$

- neto dobit $(200.000-36.000)=\underline{164.000 \mathrm{kn}}$. 
Evidentiranje poreznih učinaka privremenih razlika u poslovnim knjigama poreznog obveznika ima za posljedicu iznos neto dobiti za raspodjelu kao da je ista utvrđena primjenom zakonske porezne stope (u ovom slučaju $12 \%$ ), odnosno tim se činom efektivna porezna stopa izjednačava s nominalnom u svrhu utvrđivanja neto dobiti. Vidljivo je da postupanje s računovodstvenim načelima priznavanja poreznih učinaka privremenih razlika u godini njihova nastanka dolazi do realno iskazane dobiti tekućeg razdoblja, odnosno realno iskazanog kapitala. Posljedično, financijski izvještaji poreznog obveznika su pošteni i objektivni.

\subsection{Odbitne privremene razlike u Republici Hrvatskoj}

Nepriznavanje rashoda pri utvrđivanju osnovice poreza na dobit, a iskazanih u računovodstvu, znači da je porezna dobit veća od računovodstvene dobiti, a u budućnosti će kod ukidanja biti suprotno, tj. računovodstvena dobit će biti veća od oporezive dobiti, odnosno javljaju se odbitne privremene razlike. Odbitne privremene razlike su privremene razlike koje će imati za posljedicu iznose koji se mogu odbiti pri određivanju oporezive dobiti (poreznog gubitka) budućeg razdoblja u kojemu će knjigovodstveni iznos sredstava biti vraćen ili obveza podmirena - porez na dobit plaćen ,danas“. Zapravo, ove privremene razlike nastaju ako je računovodstvena dobit manja od oporezive dobiti, a u budućnosti će kod ukidanja biti suprotno tj. računovodstvena dobit će biti veća od oporezive dobiti. Porezni učinak ove privremene razlike iskazuje se primjenom metode odgode. Sukladno tome, privremene razlike u Republici Hrvatskoj mogu se javiti kod nepriznavanja sljedećih rashoda iskazanih u računovodstvu:

- Rashodi od nerealiziranih gubitaka (čl. 7., st. 1., t. 1. Zakona o porezu na dobit)

- Vrijednosno usklađenje i otpis potraživanja (čl. 9. Zakona o porezu na dobit)

- Vrijednosno usklađenje zaliha (čl. 10. Zakona o porezu na dobit)

- Vrijednosno usklađenje financijske imovine (čl. 10. Zakona o porezu na dobit)

- Troškovi rezerviranja (čl. 11. Zakona o porezu na dobit).

U godini nastanka privremenih razlika u poslovnim knjigama poduzetnika treba evidentirati njihov porezni učinak. Sukladno t. 47., MRS 12 - Porez na dobit porezni učinak se izračunava temeljem važeće porezne stope na dan bilanciranja (u ovom slučaju po stopi od $18 \%$ ). Porezni učinak nastale privremene razlike predstavlja odgođenu poreznu imovinu odnosno Odgođeno pokriće poreza na dobit. 
P ANIĆ-ANTIĆ, I. IDŽOJTIĆ, D. SESAR: Utjecaj učinka privremenih razlika na objektivnost financijskog izvještavanja... EKONOMSKI PREGLED, 69 (6) 744-763 (2018)

Prodajom usklađenih zaliha (porezno nepriznati rashod u godini usklađenja) dolazi do ukidanja privremenih razlika i evidentiranje pokrića poreza na dobit u poslovnim knjigama poduzetnika (porezni učinak privremenih razlika).

\section{Zaključak}

Elementi iskazani u financijskim izvještajima trebali bi iskazivati ekonomski odnosno stvarni tijek poslovnih događaja nekog poduzeća, odnosno njegovu ekonomsku stvarnost. Samo takvi financijski izvještaji mogu zadovoljiti načela fer i objektivnog izvještavanja odnosno fer i objektivnog prezentiranja financijskog položaja, uspješnosti poslovanja i novčanih tokova. Treba naglasiti da su financijski izvještaji kao finalni proizvod financijskog računovodstva namijenjeni prvenstveno vanjskim korisnicima. Upravo zbog njih se zatijeva istinitost $i$ objektivnosti informacija koje proizlaze iz financijskih izvještaja. Iz postojećeg normativnog okvira financijskog izvještavanja, vidljivo je da u Republici Hrvatskoj postoje neusklađenosti između poreznih i računovodstvenih propisa. To znači da prilikom sastavljanja financijskih izvještaja treba uzeti u obzir i mogućnost primjene načela MRS 12 i HSFI 14, odnosno nastanak/prestanak privremenih razlika, odnosno evidentiranja poreznog učinka istih. Posebno treba naglasiti posljedice promjene poreznih propisa za porezne obveznike, korisnike tzv. „novčanog načela“ kod utvrđivanja osnovice poreza na dobit. Temeljna i najvažnija posljedica primjene tog načela povlači za sobom i mogućnost nastanka privremenih razlika i na strani prihoda, što u biti po dosadašnjim poreznim propisima nije bio slučaj. To također znači i nastanak oporezivih privremenih razlika, pored dosad uobičajenih odbitnih privremenih razlika. Za potrebe fer i objektivnog financijskog izvještavanja to znači potrebu evidentiranja u poslovnim knjigama poreznih učinaka i metodom obveze, pored uobičajene metode odgode.

Posljedica nastanka i postojanja privremenih razlika, čiji porezni učinci nisu obuhvaćeni po načelima iz MRS-a 12 odnosno HSFI-a 14, je podcjenjivanje ili pak precjenjivanje dobiti nakon oporezivanja. Podcjenjena ili precijenjena dobit u godini nastanka privremene razlike znači podcjenjeni ili precijenjeni kapital odnosno podcjenjenu ili precijenjenu neto imovinu (sa svim u konačnici financijskim učincima na obujam i strukturu raspoređivanja dobiti bilo zakonskog, statutarnog, po odluci uprave ili odlukom skupštine). Zapravo, konačna posljedica je u tome što financijski izvještaji nisu pošteni i nisu objektivni. Prema Okviru za primjenu HSFI i HSFI-u 1, prema Okviru za sastavljanje i prezentiranje financijskih izvještaja i MRS-u 1 te prema čl. 15. Zakona o računovodstvu RH financijski izvještaji trebaju objektivno i istinito prezentirati financijski položaj i financijsku uspješnost. To podrazumijeva potpuno obuhvaćanje učinaka poslovnih događaja 
(uključivo i privremenih razlika), a ne djelomično. Djelomično obuhvaćanje poslovnih događaja ima za posljedicu skrivanje ili precjenjivanje njihovih financijskih učinaka, a i jedno i drugo je u izravnoj suprotnosti s propisanim zahtjevom o objektivnim i istinitim financijskim izvještajima. Stoga, potpuna primjena MRS/ MSFI pretpostavlja i primjenu načela MRS 12 (HSFI 14), odnosno računovodstveno evidentiranje nastalih razlika između računovodstvene i porezne dobiti (privremene razlike).

Kada je riječ o privremenim razlikama koje se mogu pojaviti kod poslovnih subjekata koji posluju na području Republike Hrvatske i koji za potrebe utvrđivanja porezne osnovice primjenjuju tzv. novčano načelo, obuhvat nastanka privremenih razlika je širi, što za posljedicu ima veću mogućnost pojave nepoštenog i neobjektivnog financijskog izvještavanja uslijed veće mogućnosti neobuhvata učinaka poslovnih događaja u potpunosti.

\section{Literatura:}

D. Alexander; C. Nobes: „Financial accounting: An International Introdduction, fourth edition“, Person Education Limited 2010.

Grupa autora: Primjena Hrvatskih standarda financijskog izvještavanja, RIF, Zagreb, 2008.

H.V. Greuning: „International financial reporting standards, a practical quide, Newely revised edition“, ISBN 0-8213-5910-X, The World Bank, Washington DC, 2005.

Međunarodni standardi financijskog izvještavanja (MSFI), HZRiFD, Zagreb, 2004.

Međunarodni standardi financijskog izvještavanja, eur-lex.europa.eu

P. Anić - Antić; I. Idžojtić: „Privremene razlike i učinci privremenih razlika na objektivnost financijskog izvještavanja u RH“, Ekonomski pregled br. 11., Zagreb 2012.

P. Kenkel, B. Fitzwater: „The Tax versus Book Accounting Gap“, eXtension Foundation, August 1, 2012., Oklahoma State University, USA.

Pravilnik o porezu na dobit, Narodne novine br.: 95/05, 133/07, 156/08, 146/09, 123/10, $137 / 11,61 / 12,146 / 12,160 / 13,12 / 14,157 / 14,137 / 15,1 / 17$

Zakon o porezu na dobit, Narodne novine, broj: 177/04, 90/05, 57/06, 146/08, 80/10, 22/12, 148/13, 143/14, 50/16 i 115/16.

Zakon o računovodstvu, Narodne novine, broj: 78/15,134/15 i 120/16.

http://eur-lex.europa.eu 
P ANIĆ-ANTIĆ, I. IDŽOJTIĆ, D. SESAR: Utjecaj učinka privremenih razlika na objektivnost financijskog izvještavanja... EKONOMSKI PREGLED, 69 (6) 744-763 (2018)

\title{
INFLUENCE OF EFFECTS OF TEMPORARY DIFFERENCES IN FAIR AND OBJECTIVE FINANCIAL REPORTING IN THE REPUBLIC OF CROATIA ACCORDING NEW TAX REGULATIONS
}

\begin{abstract}
Summary
The main purpose of the financial statements as the final product of financial accounting is to provide fair and fair view of the financial position and financial performance of a business entity. This assumes the application of accounting principles in. the full i.e. comprehension the financial effects of a business transactions in whole and in accordance with the nature of a business event, and not in part. The consequence of the comprehension of business events results in part is nonobjective and not fair financial reporting, either through overestimation or through underestimation elements or some positions of the elements of the financial statements. It also means that the nonrecognition of tax effects of temporary differences means incomplete application of the accounting principles of IAS 12 - Income Taxes, or CFRS 14 - Accruals, which may mean that the financial statements are neither fair nor objective. The real economic consequence of temporary differences whose tax effects are not comprised according to the IAS 12 or CFRS 14 principles is underestimation or overestimation of profit after taxation. Overestimated or underestimated profit in the year in which the temporary difference arise means under- or overestimated capital, i.e. under- or overestimated net assets (with all the eventual financial effects on the volume and structure of profit distribution). In fact, the eventual consequence is that financial statements are neither fair nor objective.
\end{abstract}

Key words: temporary differences, IAS 12, CFRS 14, financial statements, international accounting standards, income taxes 